\title{
Histopathological evaluation of endometrium and its clinical correlation in patients of abnormal uterine bleeding
}

\author{
Neha Khatik, Arti Tiwari*, Kalpana Yadav
}

\begin{abstract}
Department of Obstetrics and Gynecology, S. S. Medical College Associated Gandhi Memorial Hospital Rewa Madhya Pradesh, India
\end{abstract}

Received: 28 July 2020

Accepted: 05 September 2020

\section{*Correspondence:}

Dr. Arti Tiwari,

E-mail: artitiwari080@gmail.com

Copyright: (c) the author(s), publisher and licensee Medip Academy. This is an open-access article distributed under the terms of the Creative Commons Attribution Non-Commercial License, which permits unrestricted non-commercial use, distribution, and reproduction in any medium, provided the original work is properly cited.

\begin{abstract}
Background: Abnormal uterine bleeding (AUB) is a very common, challenging gynaecological problem in all age group women. Neoplastic lesions are responsible for very less number of cases but they should be diagnosed early. Endometrial biopsy is necessary for histopathological diagnosis of endometrial lesions and to rule out any malignancy. In present study, we evaluated histopathological pattern of endometrium and different clinical parameters in AUB patients.

Methods: A retrospective observational study done in Obstetrics and Gynecology department of SSMC Rewa, Madhya Pradesh in 2 year from $1^{\text {st }}$ October 2017 to $30^{\text {th }}$ September 2019. AUB patients who fulfilled inclusion criteria were included in study. All data were collected from department records in predesigned proforma and statistically analyzed by statistical package for the Social sciences (SPSS) version 20.

Results: Total 366 AUB patients were included in study; most frequent clinical presentation was HMB (56\%). Mostly patient's age ranged from 24-84 years, belonged to 41-50 years age group (44\%), multiparous (78\%), and premenopausal (53\%). On histopathological evaluation of endometrium most commonly nonneoplastic lesions (75\%) were seen, out of which proliferative phase endometrium was most frequent. Neoplastic lesions were seen in $25 \%$ cases. Out of which benign lesions were noted in $7 \%$, premalignant in $17.3 \%$ and malignant in $1 \%$ (all in $>45$ year patients).

Conclusions: Endometrial biopsy should be done in all AUB patients $>45$ years and in selected premenopausal in order to get early diagnosis, to rule out malignancy and to help in management. Endometrial biopsy should be considered as first diagnostic modality.
\end{abstract}

Keywords: AUB, Endometrium, Histopathological diagnosis, Perimenopausal, Postmenopausal, Premenopausal

\section{INTRODUCTION}

AUB is a very common problem faced by women of all age groups, contribute around $20-30 \%$ visits to outpatient department in reproductive age group and $69 \%$ in peri or postmenopausal age group. ${ }^{1}$ Abnormal uterine bleeding defined as bleeding from uterine cavity in absence of pregnancy and bleeding is abnormal in volume, frequency, regularity or duration. It may be acute or chronic. ${ }^{2,3}$ Abnormal uterine bleeding patterns include menorrhagia, metrorrhagia, and menometrorrhagia as well as postmenopausal bleeding (PMB). ${ }^{4}$

FIGO approved new terminologies, which are: a) Heavy menstrual bleeding (HMB) should replace menorrhagia to describe excessive bleeding, b) Inter menstrual bleeding (IMB) should replace metrorrhagia that occurs between clearly defined cyclic and predictable menses c) Heavy and prolonged bleeding (HPB) should replace menometrorrhagia and d) frequent menstrual bleeding should replace polymennorhea. ${ }^{5}$ The causes of AUB can 
be summarised using PALM-COEIN acronym in 9 categories- polyps, adenomyosis, leiomyoma, malignancy and hyperplasia- coagulopathy, ovulatory disorders, endometrial, iatrogenic and not classified. ${ }^{2,3}$

HMB is only complaint presented by nearly $40 \%$ of premenopausal women with endometrial carcinoma. Postmenopausal bleeding is an alarming symptom that indicates malignancy until proved otherwise therefore, patients with PMB requires immediate evaluation to rule out possibility of malignancy. ${ }^{6}$ Although in most cases AUB is not linked to a malignant or premalignant lesion, but in PMB risk of endometrial cancer is $10 \%$ so, PMB should not be taken lightly., ${ }^{7,8}$ Rate of progression to cancer is $1 \%$ in simple endometrial hyperplasia, $3 \%$ in complex hyperplasia, and $8 \%$ in simple atypical hyperplasia, whereas complex atypical hyperplasia had $29 \%$ progression rate to cancer. ${ }^{9}$ So, it is important to evaluate endometrium in AUB patients through endometrial biopsy to rule out malignancy and diagnose premalignant lesion at an early stage.

For proper management of patient, detailed history, clinical examination and ultrasonography is required which can detect bleeding source but histopathological diagnosis is also needed especially in perimenopausal and postmenopausal AUB patient to rule out any malignancy and for deciding mode of treatment-either medical or surgical. For histopathological diagnosis, endometrial tissue can be obtained from several techniques but dilatation and curettage is preferred method for biopsy. Fractional curettage allows separate endometrial and endocervical tissue sampling.

In postmenopausal women risk stratification can be done, endometrial thickness (ET) $<4 \mathrm{~mm}$ in transvaginal sonography shows risk of endometrial carcinoma below $1 \% .^{10}$ In premenopausal women with AUB this risk stratification is not possible because prediction through ET not showed good results and results are conflicting. ${ }^{11-}$ 13 Some guidelines recommend endometrial biopsy as mandatory in women over the age of 40 , or under the age of 40 in the presence of comorbidities. ${ }^{14,15}$.The UK NICE guidance recommends endometrial biopsy in Premenopausal women with failed medical treatment, with persistent intermenstrual bleeding (IMB), and for women over the age of 45 with heavy menstrual bleeding (HMB). ${ }^{16,17}$

In present study we reviewed different clinical parameters, histopathological patterns of endometrial biopsy in AUB patients.

\section{Aims and objective}

Evaluate histopathology of endometrium for identifying the endometrial cause of AUB and know the incidence of various pathology in different age groups presenting with AUB.

\section{METHODS}

This was a retrospective study done on patients with chief complaints of AUB in department of obstetrics and gynecology, Shyam Shah Medical College Rewa who subjected for endometrial biopsies over a period of 2 years from $1^{\text {st }}$ October 2017 to $30^{\text {th }}$ September 2019. Total 366 women in the age group of 24-84 year were enrolled in our study after fulfilling the inclusion criteria.

\section{Inclusion criteria}

All AUB patients age $>45$ years or postmenopausal bleeding; Heavy menstrual bleeding with endometrial thickness $>12 \mathrm{~mm}$ on ultrasound in reproductive age group. ${ }^{18}$ Persistent intermenstrual bleeding; patient not responding to medical treatment; AUB patient who have risk factor for endometrial carcinoma; and patient not responding to medical treatment

\section{Exclusion criteria}

Inadequate samples; AUB due to bleeding disorders, cervical pathology, leiomyoma, vaginal pathology and pregnancy related bleeding; and follow up cases of endometrial malignancies

Patients were divided in 3 groups according to age- 1 . Premenopausal (21-45 years) 2. Perimenopausal (>45 years till menopause) and 3. Postmenopausal (after menopause). Patients were also categorized in 5 groups on the basis of complaints- heavy menstrual bleeding (HMB), heavy prolong bleeding (HPB), inter menstrual bleeding (IMB), short menstrual bleeding (SMB) and postmenopausal bleeding (PMB).

Data of patients were collected from department records. Relevant basic information of patients like clinical details, histopathological diagnosis of endometrial biopsy, management details were filled in predesigned proforma. Data was analysed by using statistical package for social science (SPSS version 20). Analysis was done in propotion and percentage and represented in tables and graphs as necessary.

\section{RESULTS}

Total 366 women having abnormal uterine bleeding were enrolled in study. Patient's age ranged from 24-84 years. Out of 366 mostly patients belonged to 41-50 years age group (44\%), multiparous (78\%), and in reproductive age group (premenopausal) followed by perimenopausal (Table 1).

Most common clinical presentation was HMB (56\%), followed by IMB in $21 \%$ and PMB in $16 \%$. Mostly patients had symptoms for less than 1 year (Table 2).

Endometrial biopsies in AUB patients showed wide range of changes on histopathological examination from normal 
endometrium to malignancy. In overall AUB patients, non-neoplastic lesions were most common, found in $75 \%$ cases and neoplastic lesions in $25 \%$. Proliferative endometrium (42\%) was most common finding followed by simple endometrial hyperplasia without atypia (13\%), secretory endometrium (12\%), atrophic (7\%) and disordered proliferative in $(6 \%)$ (Figure 1).

Table 1: Demographic characteristics of AUB patients.

\begin{tabular}{|llll|}
\hline Variables & & $\begin{array}{l}\text { Number of } \\
\text { patients }\end{array}$ & $\%$ \\
\hline \multirow{2}{*}{$\begin{array}{l}\text { Age wise } \\
\text { distribution } \\
\text { in years }\end{array}$} & $21-30$ & 17 & 5 \\
\cline { 2 - 4 } & $31-40$ & 143 & 39 \\
\cline { 2 - 4 } & $41-50$ & 163 & 44 \\
\hline \multirow{3}{*}{ Parity } & $>50$ & 43 & 12 \\
\cline { 2 - 4 } & Primipara & 80 & 22 \\
\hline \multirow{2}{*}{$\begin{array}{l}\text { Menstrual } \\
\text { status }\end{array}$} & Grand multipara & 110 & 48 \\
\cline { 2 - 4 } & Premenopausal & 195 & 30 \\
\cline { 2 - 4 } & Perimenopausal & 111 & 30 \\
\hline
\end{tabular}

Table 2: Clinical parameters of AUB patients.

\begin{tabular}{|llll|}
\hline \multirow{4}{*}{ Variables } & & \multicolumn{1}{c}{$\begin{array}{l}\text { Number of } \\
\text { patients }\end{array}$} & Percentage \\
\hline \multirow{3}{*}{ Complaint } & HMB & 206 & 56 \\
\cline { 2 - 4 } & HPB & 22 & 6 \\
\cline { 2 - 4 } & IMB & 76 & 21 \\
\cline { 2 - 4 } & PMB & 60 & 16 \\
\cline { 2 - 4 } & SMB & 2 & 1 \\
\hline \multirow{2}{*}{$\begin{array}{l}\text { Duration of } \\
\text { complaint }\end{array}$} & $<1$ year & 162 & 44 \\
\cline { 2 - 4 } & 1-5 years & 124 & 34 \\
\cline { 2 - 4 } & $>5$ years & 80 & 22 \\
\hline
\end{tabular}

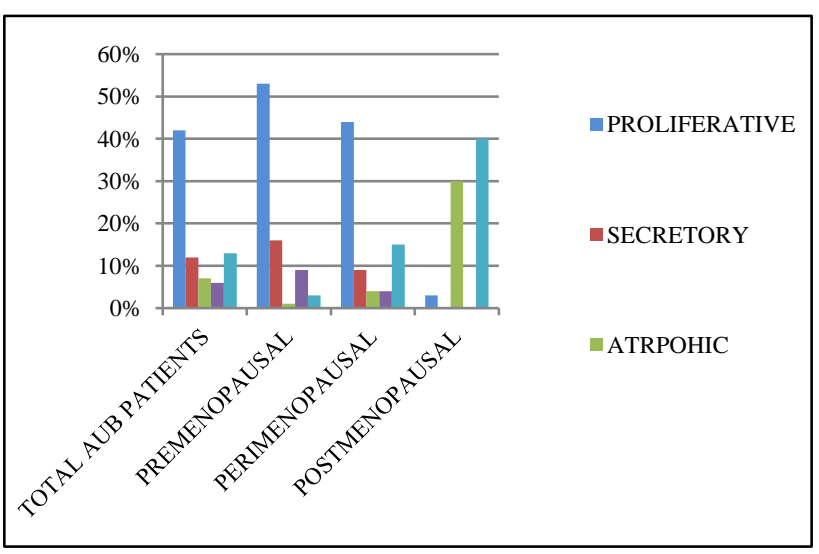

Figure 1: Common endometrial biopsy finding in AUB patients

Over all benign lesions (endometrial polyp- 4\% and leiomyomatous polyp- 3\%) were noted in $7 \%$ cases. Premalignant lesions (hyperplasia) were reported in $17.3 \%$ cases and malignancy was noted in $1 \%$ ( 3 cases).
In total AUB patients, women belong to premenopausal age group were 195 out of $366(53 \%)$. In premenopausal women, most common histopathological finding was proliferative phase endometrium (53\%), followed by secretory phase $(16 \%)$ and disordered in $9 \%$ cases. In perimenopausal group (111 cases/30\%), most frequent finding was proliferative $(44 \%)$, followed by simple endometrial hyperplasia (15\%). In postmenopausal group of AUB patients, total cases were 60 (17\%), simple endometrial hyperplasia (40\%) was most frequent finding followed by atrophic endometrium (30\%) (Table 3, Figure 1).

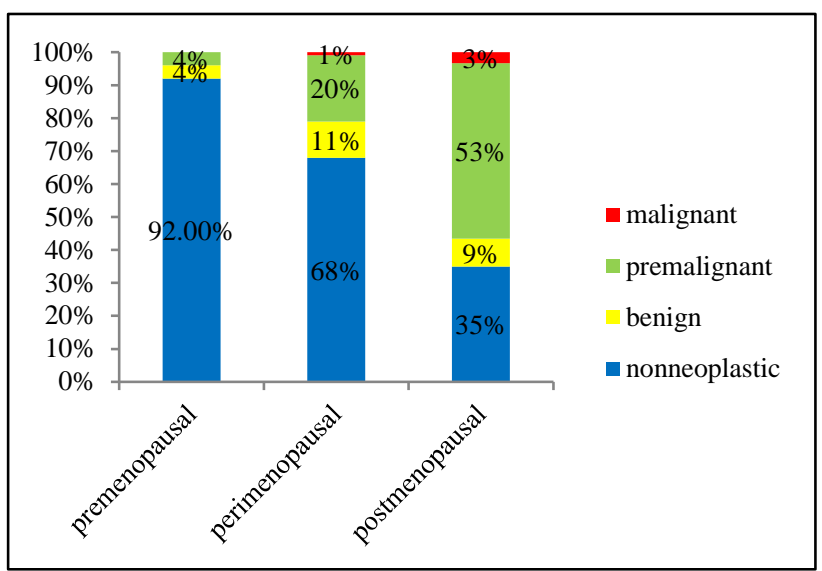

Figure 2: Histopathological distribution of endometrial lesion on endometrial biopsy according to menstrual status.

Most cases of premalignant and malignant lesions were seen in peri and postmenopausal patients. Around 4/5 neoplastic lesions were seen in peri and postmenopausal patients. In premenopausal age group, neoplastic lesions (benign and premalignant) were found only in $8 \%$ cases $(n=195)$, out of which simple endometrial hyperplasia without atypia found in 6 patients, simple endometrial hyperplasia with atypia in 1 and complex endometrial hyperplasia in 1 patient. Not a single patient reported malignancy in premenopausal group. Highest number of neoplastic lesions was found in postmenopausal group followed by perimenopausal group of AUB patients. Premalignant and malignant lesions were seen maximum in postmenopausal patients, in $53 \%$ and $3 \%$ cases out of 60 cases followed by perimenopausal age group in $20 \%$ and $1 \%$ cases out of 111 cases respectively (Table 3 and Figure 2).

Among premalignant, simple endometrial hyperplasia without atypia was most common, found in 17 patients in perimenopausal and in 24 patients in postmenopausal. Next most common finding was simple endometrial hyperplasia with atypia, found in 3 AUB patients in perimenopausal group and in 5 in postmenopausal group. Complex endometrial hyperplasia without atypia was seen in 2 patients in peri and 2 patients in postmenopausal group. Complex endometrial hyperplasia with atypia was seen in 1 patient in postmenopausal 
group. In malignant lesions, endometrial adenocarcinoma was seen in 2 patients in postmenopausal and 1 in perimenopausal group (Table 3, Figure 2).

Table 3: Histopathological pattern of endometrial biopsy in AUB patients.

\begin{tabular}{|c|c|c|c|c|c|}
\hline Biopsy lesions & Histopathological diagnosis & $\begin{array}{l}\text { No. of pre } \\
\text { menopausal } \\
\text { women }\end{array}$ & $\begin{array}{l}\text { No. of peri } \\
\text { menopausal } \\
\text { women }\end{array}$ & $\begin{array}{l}\text { No. of post } \\
\text { menopausal } \\
\text { women }\end{array}$ & Total \\
\hline \multicolumn{2}{|c|}{ Endometrial lesion } & $195(53 \%)$ & $111(30 \%)$ & $60(17 \%)$ & 366 \\
\hline \multicolumn{2}{|c|}{ Nonneoplastic lesions } & $179(49 \%)$ & $76(21 \%)$ & $21(5 \%)$ & $276(75 \%)$ \\
\hline \multirow{3}{*}{$\begin{array}{l}\text { Normal } \\
\text { endometrial } \\
\text { pattern }\end{array}$} & Proliferative phase & 103 & 49 & 02 & $154(42 \%)$ \\
\hline & Secretory phase & 32 & 11 & 00 & $43(12 \%)$ \\
\hline & Atrophic phase & 02 & 05 & 18 & $25(7 \%)$ \\
\hline \multirow{3}{*}{$\begin{array}{l}\text { Other than } \\
\text { normal }\end{array}$} & Disordered proliferative phase & 19 & 05 & 00 & $24(6 \%)$ \\
\hline & Hormonal induced changes & 14 & 04 & 00 & $18(5 \%)$ \\
\hline & Out of phase secretory & 02 & - & - & $02(0.6 \%)$ \\
\hline Inflammatory & Endometritis & 07 & 02 & 01 & $10(3 \%)$ \\
\hline \multicolumn{2}{|c|}{ Neoplastic lesions } & $16(4 \%)$ & $35(10 \%)$ & $39(11 \%)$ & $90(25 \%)$ \\
\hline \multirow{2}{*}{ Benign lesions } & Endometrial polyp & 06 & 06 & 02 & $14(4 \%)$ \\
\hline & Leiomyomatous polyp & 02 & 06 & 03 & $11(3 \%)$ \\
\hline \multirow{4}{*}{$\begin{array}{l}\text { Premalignant } \\
\text { lesions }\end{array}$} & Simple endometrial hyperplasia without atypia & 06 & 17 & 24 & $47(13 \%)$ \\
\hline & Simple endometrial hyperplasia with atypia & 01 & 03 & 05 & $09(3 \%)$ \\
\hline & $\begin{array}{l}\text { Complex endometrial hyperplasia without } \\
\text { atypia }\end{array}$ & 01 & 02 & 02 & $05(1 \%)$ \\
\hline & Complex endometrial hyperplasia with atypia & - & - & 01 & $01(0.3 \%)$ \\
\hline $\begin{array}{l}\text { Malignant } \\
\text { lesions }\end{array}$ & Endometrial adenocarcinoma & - & 01 & 02 & $03(1 \%)$ \\
\hline
\end{tabular}

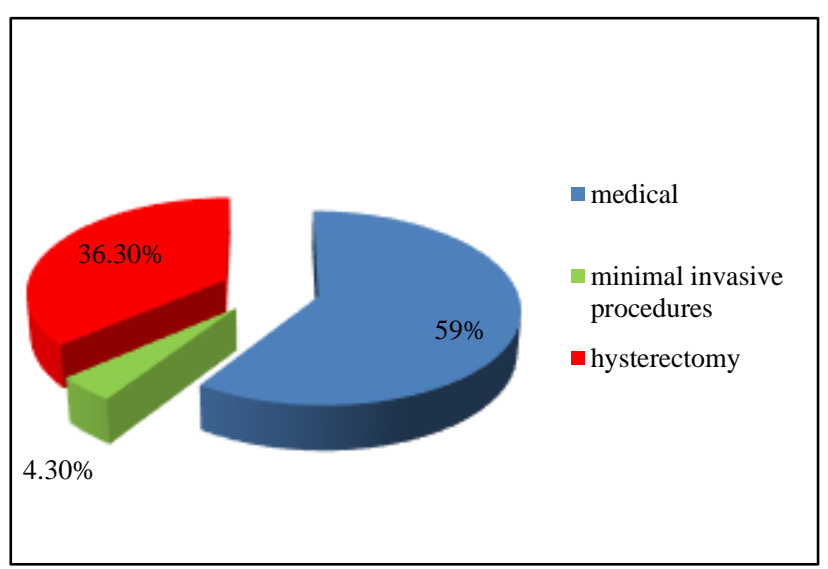

Figure 3: Treatment method used in AUB patients.

Out of 366 patients, maximum patients were responded to medical treatment $(59 \%)$, few patients were required minimal invasive procedure like polypectomy/ myomectomy). Only $36 \%$ patients required hysterectomy as final treatment. Mostly patients who were undergone hysterectomy were in peri and postmenopausal age group (Figure 3).

\section{DISCUSSION}

Histopathological evaluation of AUB patients is very important not only to rule out malignancy but also to identify different causes of AUB. Thus, endometrial biopsy along with clinical findings and imaging studies help in deciding the treatment modalities in AUB patients.

In present study most of AUB patients belonged to 41-50 year age group, multiparous and had $\mathrm{HMB}$ as main complaint same as Shukla et al. ${ }^{19}$ Bashir et al also found menorrhagia $(56.73 \%)$ as most common presenting complaint. ${ }^{20}$ Incidence of heavy menstrual bleeding in this age group is more common; this may be due to the fact that as women approaches menopause, decrease number of ovarian follicle and increase resistance to gonadotropic stimulation, result in anovulatory cycles. Sustain high level of estrogen followed by transient fall result in focal breakdown of an overgrown and structurally fragile endometrium that leads heavy flow during menses.

In present study mostly AUB patients were in premenopausal status $(53 \%)$ followed by perimenopausal (30\%) and postmenopausal status (17\%). Similar age distribution was seen in study done by Tiwari et al in Nepal showed premenopausal women were $60 \%$, perimenopausal were $23 \%$ and $17 \%$ were postmenopausal. ${ }^{21}$

Out of 366 cases, $276(75 \%)$ cases had non neoplastic lesions and $90(25 \%)$ had neoplastic lesions, normal 
endometrial pattern (61\%) was most frequent finding out of nonneoplastic lesions. Tiwari et al also found same as our study, non neoplastic lesions were in $85 \%$ cases and neoplastic in $15 \%$ cases and out of nonneoplastic normal endometrial pattern was most common $(50 \%) .{ }^{21}$ Both had proliferative phase most common in normal pattern. The bleeding in proliferative phase may be due to anovulatory cycles and in secretory phase due to ovulatory dysfunctional uterine bleeding.

In present study, disordered proliferative pattern was seen in $6 \%$ of cases, incidence is lower as compared to results shown by Tiwari et al (19\%). ${ }^{21}$ A disordered proliferative endometrium term is used for proliferative endometrium that does not seem appropriate for any one time in the menstrual cycle and mimic simple hyperplasia but changes are focal rather than diffuse. It represents earliest stage of endometrial carcinoma spectrum and detection of disease at this stage help in prevention of disease progression. Low incidence of disordered proliferative endometrium compared to endometrial hyperplasia in present study suggests low level of awareness regarding their health in females of Vindhya region.

In our study hormonal effect (exogenous administration) was noted in $5 \%$ of cases out of which 14 cases were seen in premenopausal age group. Bashir et al have reported 2$3 \%$ incidence in their study. ${ }^{20}$

In our study inflammatory pattern (endometritis) was accounted in $3 \%$ of cases same as Mani et al $(1.8 \%)$, Bashir et al $(2.6 \%)$ and Vaidya et al $(3.23 \%){ }^{20,22,23}$ Chronic endometritis can cause AUB, pelvic pain and infertility. This condition is frequently seen after IUCD insertion and incomplete abortion. The condition need to be diagnosed because specific treatment results in normal functioning endometrium.

In present study endometrial polyp was found in $4 \%$ cases and leiomyomatous polyps in $3 \%$ cases. Similar incidences of 2-3\% were reported by different studies. ${ }^{20,21,24}$ Most cases of endometrial polyp were seen before menopause. Endometrial polyp has different receptor expression, cell proliferation and apoptosis regulation as compared to normal endometrium. These differences along with chromosomal aberrations and monoclonal nature suggest that polyp may provide suitable microenviroment for development of malignancy. ${ }^{25}$

In present study, atrophic endometrial pattern was seen in $7 \%$ of cases and predominantly in postmenopausal age group. The incidence is similar to study done by Doraiswami et al and lower when compared with results shown by Gredmark et al. ${ }^{26,27}$ Decrease level of endogenous hormones in postmenopausal age group result in abnormality in local hemostatic mechanism, thinning of endometrial vein which make vessel prone to injury.
In our study endometrial hyperplasia were seen in $17.3 \%$ cases and most cases were in peri and postmenopausal women $\left(4 / 5^{\text {th }}\right.$ cases $)$. An incidence of $13-20 \%$ for endometrial hyperplasia has been reported in other similar studies. ${ }^{20,24,28}$

In our study, overall incidence of endometrial carcinoma was $0.8 \%$ and in postmenopausal women it was observed in $3 \%$ of cases. Aslam et al (1\%), Bashir et al (1.52\%), Dhakal et al $(2 \%)$ reported similar incidence whereas higher prevalence of malignancy was reported by Dangal et al $(17.6 \%)$ and Baral et $\mathrm{al}^{24}(21 \%)$. $^{20,24,29-31}$ Low prevalence of endometrial carcinoma in our study may be due to women in our continent have child bearing at an early age and multiparous. Other possible explanation could be that most of the patients here belong to low socioeconomic category and prevalence of diabetes, obesity, hypertension and sedentary life style is low as compared to high socioeconomic status females.

The causes of AUB vary with respect to the age of patients. In our study most of the women (53\%) belonged to premenopausal age group and proliferative endometrium (42\%) was most common observed endometrial abnormality followed by simple endometrial hypeplasia (26\%). Similar results was observed by Doraiswami et al while study conducted by Sarwar et al showed contradict findings in which most common pattern was hormonal imbalance. ${ }^{26,32}$ In perimenopausal age group most common endometrial abnormality was proliferative endometrium followed by simple endometrial hyperplasia in present study.

As in present study, 53\% women belonged to premenopausal age group and $61 \%$ has normal endometrial pattern on histology, most of the patients respond to medical treatment $(59 \%)$, few responded to minimal invasive procedure $(4.3 \%)$ like polypectomy, myomectomy and $36 \%$ cases required hysterectomy at last.

\section{CONCLUSION}

Histopathological evaluation of endometrium in patients with AUB showed wide range of histological pattern ranging from normal endometrium to malignancy. Endometrial cause of AUB is age related pathology. In our study we came to know that most cases of malignancy are found in perimenopausal and postmenopausal women and in premenopausal age group chances of malignancy are very less but not impossible. Endometrial biopsy gives us opportunity to diagnose organic lesion like polyp and hyperplasia thereby help in early diagnosis of premalignant and malignant lesion of endometrium.

So endometrial biopsy should be considered as major tool in diagnostic evaluation of AUB and specific diagnosis could help the clinician to plan therapy for successful management of AUB. 
Funding: No funding sources

Conflict of interest: None declared

Ethical approval: The study was approved by the Institutional Ethics Committee

\section{REFERENCES}

1. American College of Obstetricians and Gynecologists. Management of anovulatory bleeding. ACOG Practice Bulletin No. 14. Washington, DC: ACOG; 2000.

2. Munro MG, Critchley HO, Broder M, Fraser ID. FIFWGoM FIGO classification system (PALMCOEIN) for causes of abnormal uterine bleeding in non gravid women of reproductive age. Int J Gynecol Obstet. 2011;113(1):3-13.

3. American College of Obstetricians and Gynecologists. Diagnosis of abnormal uterine bleeding in reproductive-aged women: Practice Bulletin No. 128. Obstet Gynecol. 2012;120:197206.

4. Fraser IS, Critchley HO, Munro MG. Abnormal uterine bleeding: getting our terminology straight. Curr Opin Obstet Gynecol. 2007;19(6):591-5.

5. Munro MG, Critchley HO, Fraser IS. The FIGO systems for nomenclature and classification of causes of abnormal uterine bleeding in the reproductive years: who needs them? Am J Obstet Gynecol. 2012;207(4):259-65.

6. Dutta DC. Abnormal menstrual bleeding. 4th ed. Konar H, editor. Text book of gynaecology including contraception. New central book agency (P) Ltd; 2003:175-186.

7. Bignardi T, Van den Bosch T, Condous G. Abnormal uterine and post-menopausal bleeding in the acute gynaecology unit. Best Pract Res Clin Obstet Gynaecol. 2009;23(5):595-607.

8. Giannella L, Mfuta K, Setti T, Cerami LB, Bergamini E, Boselli F. A risk-scoring model for the prediction of endometrial cancer among symptomatic postmenopausal women with endometrial thickness> 4 mm. BioMed Res Int. 2014;2014.

9. Chiang JW, Wilcox N. Premalignant lesions of the endometrium. WebMD Professional. 2011.

10. Van Hanegem N, Breijer MC, Khan KS, Clark TJ, Burger MP, Mol BW, Timmermans A. Diagnostic evaluation of the endometrium in postmenopausal bleeding: an evidence-based approach. Maturitas. 2011;68(2):155-64.

11. Özdemir S, Çelik Ç, Gezginç K, KIreşi D, Esen H. Evaluation of endometrial thickness with transvaginal ultrasonography and histopathology in premenopausal women with abnormal vaginal bleeding. Arch Gynecol Obstet. 2010;282(4):395-9.

12. Kim M, Kim J, Kim SM. Endometrial evaluation with transvaginal ultrasonography for the screening of endometrial hyperplasia or cancer in premenopausal and perimenopausal women. Obstet Gynecol Sci. 2016;59(3):192.
13. Van den Bosch T, Ameye L, Van Schoubroeck D, Bourne T, Timmerman D. Intra-cavitary uterine pathology in women with abnormal uterine bleeding: a prospective study of 1220 women. Facts Views Vis Obgyn. 2015;7( 1):17-24.

14. Royal College of Obstetricians and Gynaecologists. Standards for gynaecology: report of e working party. London: RCOG, 2008.

15. Singh S, Best C, Dunn S, Leyland N, Wolfman WL, Wolfman W, et al. Abnormal uterine bleeding in premenopausal women. J Obstet Gynaecol Canada. 2013;35(5):473-5.

16. National Institute for health and clinical excellence CG44. Heavy menstrual bleeding. NICE, 2007.

17. Committee on Practice Bulletins- Gynecology. Practice bulletin no. 128: diagnosis of abnormal uterine bleeding in reproductive-aged women. Obstet Gynecol. 2012;120(1):197-206.

18. Casablanca Y. Management of dysfunctional uterine bleeding. Obstet Gynecol Clin North Am. 2008;35:219-34.

19. Shukla M, Fonseca MN, Kharat D, Tekale P. A study to correlate histopathological findings in patients with abnormal uterine bleeding. Int $\mathbf{J}$ Reprod Contracept Obstet Gynecol. 2017;6:654-7.

20. Bashir H, Bhat N, Khuroo MS. Clinicopathological study of endometrium in patients with abnormal uterine bleeding. Int J Cur Res Rev. 2015;7(22):6773.

21. Tiwari A, Kaur N, Jain S, Rai R, Jain SK. Histopathological study of endometrial biopsy specimens for abnormal uterine bleeding. J Lumbini Med Coll. 2016;4(2):72-6.

22. Mani R, Nayak S, Kagal A, Bharadwaj R. Tuberculous endometritis in infertility: a bacteriological and histopathological study. Indian J Tubercul. 2003;50:161

23. Vaidya S, Lakhey M, Vaidya S, Sharma PK. histopathological pattern of abnormal uterine bleeding in endometrial biopsies. Nepal Med Coll J. 2013;15:74-7.

24. Baral R, Pudasaini S. Histopathological pattern of endometrial samples in abnormal uterine bleeding. $\mathrm{J}$ Pathol Nepal. 2011;1(1):13-6.

25. Hileeto D, Fadare O, Martel M, Zheng W. Age dependent association of endometrial polyps with increased risk of cancer involvement. World J Surg Oncol. 2005;3(1):1-6.

26. Doraiswami S, Johnson T, Rao S, Rajkumar A, Vijayaraghavan J, Panicker VK. Study of endometrial pathology in abnormal uterine bleeding. J Obstet Gynaecol India. 2011;61:426.

27. Gredmark T, Kvint S, Havel G, et al. Histopathological findings in women with postmenopausal bleeding. B J Obstet Gynaecol. 1998;102:133-6.

28. Patil SG, Bhute SB, Inamdar SA. role of diagnostic hysteroscopy in abnormal uterine bleeding and histopathologic correlation. J Gynecol Endosc Surg. 2009;1:98-104. 
29. Aslam M, Ijaz L,Tariq S, Shafqat K, Meher-un-Nisa, Ashraf R, et al. Comparison of Transvaginal sonography and saline contrast sonohysterography in women with abnormal uterine bleeding: correlation with hysteroscopy and histopathology. Int J Health Sci (Qassim). 2007;1(1):17-24.

30. Dhakal HP, Pradhan M. Histological pattern of gynecological cancers. JNMA J Nepal Med Assoc. 2009;48:301-5.

31. Dangal G. Endometrial study of abnormal uterine bleeding in women at 45 years and above. JNMA J Nepal Med Assoc. 2003;42:83-5.
32. Sarwar A, Haque A. Types and frequencies of pathologies in endometrial curettings of abnormal uterine bleeding. Int J Pathol. 2005;3(2):65-70.

Cite this article as: Khatik N, Tiwari A, Yadav K. Histopathological evaluation of endometrium and its clinical correlation in patients of abnormal uterine bleeding. Int J Reprod Contracept Obstet Gynecol 2020;9:4169-75. 